\title{
PODCASTS AND JOURNALISM
}

\begin{abstract}
The application of new technologies in journalism contributes to the development of new forms of journalistic content. Podcasts that present content posted online and allow online users to access them whenever and however many times they want are experiencing continued success around the world (Newman, 2021). This development has also led to a variety in the content of podcasts, and the approach to topics is journalistic in some podcast series. Podcast authors can be journalists, as well as other people, Internet users and sometimes celebrities. For example, it is predicted that this year there will be a "battle for the stars" between the platforms and the media. The aim of this paper is mapping the use of podcasts in Serbia, starting, above all, from podcasts as journalism technology. A few years ago, the traditional mainstream media in Serbia tried to keep pace with the innovators in the online environment and increase attendance at their online editions. The results of this research show that the podcast develops in two ways when it comes to journalism: as part of the online media and as an individual endeavor of the author. It can be concluded that the podcast that is the individual endeavor of the author, considering that it is realized outside the media institution, is a freer form of expression and is often very popular. Finally, since the podcast technology is cheaper than radio or television broadcasting and that this broadcasting does not require the permission of the regulatory body, it is run by other companies, not just media companies..
\end{abstract}

Key words: podcast, journalism, digital technologies, online audience, media

\section{Introduction}

The popularity of podcasts is growing worldwide - their number is on the rise, and the audience is growing too. Data from the research conducted by the Reuters Institute for Journalism "Digital news report" show that $31 \%$ of survey participants listened to a podcast at least once a month, which is an increase of $2 \%$ compared to 2018 (Newman et al., 2020). This is accompanied by financial results. It is estimated that this market will grow and that by 2025 it will amount to 3.3 billion euros globally, which is three times more than its current value. Although most of the revenue comes

\footnotetext{
${ }^{1}$ This paper was presented at the Regional Conference " 30 years of higher education in journalism and communication in Eastern Europe after 1989: From conquering the freedom of expression to embracing digital communication", which was held on 21 May 2021 (online conference).

${ }^{2}$ Received June 2021 / Accepted August 2021

${ }^{3}$ e-mail: anka.mihajlov.prokopovic@filfak.ni.ac.rs
} 
from advertisers, there has also been an increase in models based on user payment (Newman, 2021). In Serbia, only one podcast is financially viable. It is a podcast called "Alarm" created by two authors known as Daško and Mladja, which is funded by the money paid by the listeners. On the https://podcast.rs/ platform which is an aggregator ${ }^{4}$ for podcasts from Serbia and the region, there are 203 podcasts (List of podcasts, May 14, 2021). This new media format wishes to accommodate the audience and provide better experience so that everyone can listen to podcasts on the go, while driving or while doing something else. Moreover, many podcasts are created as a result of the users' desire to start a conversation on a certain topic and are part of user-generated content. Vladimir Radinović, one of the people working on the Podcast.rs platform, explains it in this way: "You no longer have to be part of a traditional radio newsroom to produce good-quality radio content. Podcasts are a free form and anyone can be an author and cover a specific topic that is interesting to him/her and thus build a community around that topic and his/her podcast on the Internet. There are no editors and no time limit; each topic is covered as much as necessary to get to the essence and as much as the authors and guests want it" (Dašić, 21 October 2020).

This media form is not subject to any strict rules of journalism regarding style, genre and a hierarchical editorial structure when initiated as a native, outside of media organizations. The second type of podcast - informative podcasts published by the mainstream media ${ }^{5}$ have some of these characteristics. That is why the mainstream media often carefully choose who will host the podcast and these podcasts also strive for an informal style. Here is how Anushka Asthana, the main host of the Guardian's Today in Focus podcast, explains this: "You've got to be physically warm and have a bit of a laugh with it and really feel like you're in the room with the interviewee so that you can react to what they're saying. We really structure interviews - that's part of the trick of these things - but you shouldn't squeeze all the fun and warmth out of it, which is the risk" (Newman \& Gallo, 2020: 17).

According to the results reported by Newman, informative podcasts achieved audience growth in 2020 and only humorous podcasts were more popular in terms of audience (Newman, 2021). Thus, there has been a total of 100 new daily news podcasts, which are, without a doubt, inspired by the great success of the daily informative podcast "The Daily" launched by the New York Times, which in 2021

\footnotetext{
4 "Aggregator is a website or program that collects related content and displays it in one place or combines links to them. Aggregators can be treated as intermediaries, facilitating communication between users and third parties whose information and content are available online. Aggregators provide access to aggregated information and content, but can also 'host' it (display it on their pages), transmit it and tag it. Aggregators select and integrate content according to predefined, automated systems and then that content is made available to users, making aggregators a kind of content editor" (Martinoli, 2020: 25).

5 "The term mainstream refers to ideas, attitudes or activities that are shared by the majority of people and that are considered common and conventional. In the case of media, the term mainstream refers to official, institutionalized media channels and traditional forms of media such as daily newspapers, television and radio, rather than the Internet. The mainstream media in their content present the most widely accepted attitudes and beliefs" (Cambridge Dictionary - Mainstream Media, in Martinoli, 2020: 19).
} 
has four million listeners a day; this is almost twice as many listeners as the New York Times had readers in its most successful period (Newman, 2021). "The Daily" is published five days a week, usually lasts for 20 minutes and "is powered by the New York Times journalism" ("The Daily", 13 May 2021). As it can be seen, "The Daily", although presenting innovative audio content, also takes into account the exemplary high-quality journalism that is characteristic of the New York Times. In order to meet the information needs of the audiences, large media companies ( $C N N$, $B B C$, etc.) launched podcasts with specialized content about the epidemic caused by the coronavirus. Research conducted by the Reuters Institute for Journalism "Digital news report" (2020) conducted in 40 countries on six continents found that more than $50 \%$ of participants believe that through podcasts they get a deeper insight when it comes to current events (Newman et al., 2020).

This paper aims to present the academic efforts in studying this topic and to map the use of podcasts in Serbia, starting, above all, from podcasts as a technology of journalism. The research question is whether podcasts are used in Serbia to publish journalistic content. This paper analyzes the podcast landscape in Serbia and interprets the results of several previous studies on podcasting in Serbia (Centar za medijska istraživanja [Center for Media Research], 2020; Drašković \& Prodanović, 2017; Martinoli, 2020). The analysis included the recently launched the https:// podcast.rs/ platform, which contains podcasts from Serbia and the region.

The first part of the paper will analyze the relationship between journalism and technology and the impact of technology that leads to changes in journalism. Then, a new technology of journalism will be considered - podcasting and its characteristics and definition. In the next part of the paper, the author will analyze podcasts in Serbia, with the aim of identifying a group of podcasts that broadcast journalistic content initiated by media organizations or journalists in order to identify the differences that exist between them.

\section{The relationship between journalism and technology}

The changes that being digital, as digital transformation at an early stage is called by the theorist from MIT (Massachusetts Institute of Technology) Nicholas Negroponte, in his book "Being Digital" (1998), which is seen as the manifesto of the digital age, brought to the media industry are immense. They enabled the convergence of the formerly divided media companies and parts of the media industry. Thanks to digitalization, the film and television industry, the print and publishing industry and the computer industry have merged. Negroponte and his associates schematically presented this through three circles that partially overlap (Fidler, 2004).

Convergence, as perhaps the greatest change brought about to the media industry by digitalization, has also been addressed by Henry Jenkins, who mentions several types of convergence: technological, economic, social, cultural, and global (Jenkins, 2001). He speaks of convergence as a "social change", pointing out that now, thanks 
to any digital connection (e.g., mobile phone), anyone can access the content they need at any time and any place, including media content (Jenkins, 2006). All of this has inevitably led to changes in the organization of journalistic media companies and to changes in their established professional practices (Boczkowski, 2004; Deuze, 2007; Kung, 2015; Paulussen, 2016; Weiss \& Joyce, 2009). At the beginning of the digital transformation of large, influential and reputable news companies in the United States, the problem encountered was the resistance by editorial staff to the introduction of new rules and practices - the theorist Pablo Boczkowski calls this the clash of two journalistic cultures. Boczkowski visited the editorial offices of three American dailies to observe and analyze the changes in journalistic practices brought about by digitalization (Boczkowski, 2004). He concluded that those media companies whose online edition was not closely related to the traditional edition were more innovative; they changed the existing editorial practices and perceived their audiences as technically advanced users (Boczkowski, 2004).

This was later conceptualized by Alfred Hermida, who as a journalist was the founder of the $B B C$ website. The characteristics of the first culture that developed during modernism are that the text published in the newspaper was the result of work and agreement between editors and journalists, and that once published it could not be easily changed and that the audience had almost no influence on the texts (Hermida, 2014: 364). In the contemporary media world, the management of media journalism companies cannot be imagined without a strategy that focuses on the digital audience and its influence not only on the reception, but also on the production of content. This can be seen in the emergence of new professions (bloggers, social media managers), changes in the existing work practices (multitasking and writing for multiple platforms), and new journalistic genres in which journalists and users collaborate (in informative journalism it is a live blog).

Traditional media go where their audience is and the observed trends show that, nowadays, the audience is on social media and that there it follows the news in a special way that even got its unique name. It is called incidental news consumption. Namely, there has been a change in the pattern of news consumption, especially among young audiences. In "Incidental News: How Young People Consume News on Social Media", Boczkowski and Mitchelstein point to a pattern in which young users do not seek news but are exposed to it by becoming part of the content they access while on social media (Boczkowski \& Mitchelstein, 2017). As a result, "news consumption is integrated into broader patterns of social media sociability, but at the expense of understanding the news report as a unique entity that deserves special attention and has an integrity of its own - the notion that a newspaper or a television show is an authoritative rendition of the day's main events loses significance in the social media maelstrom" (Boczkowski \& Mitchelstein, 2017: 1785-1786). The consequences of this trend are already visible, the authors point out: firstly, media no longer necessarily impose what the most important events of the day are, these are actually identified by the users themselves, and secondly, young users follow the recommendations - shares or retweets, of their contacts on social media. 


\section{Many faces of journalism in the digital age: podcasts and journalism}

Web 2.0 and the online social media opportunities it brought have enabled the development of online journalism in many directions. In the beginning, before Web 2.0, online journalism fought for its legitimacy against traditional types of journalism (Allan, 2006). Later on, thanks to the use of Web 2.0 and many technological innovations, mobile journalism, drone journalism and other new forms of journalism that are connected with social media and more recently to artificial intelligence, have emerged.

Podcasts are an opportunity for decentralized audio content to be widely available online. The first podcasts that appeared in 2004 were the result of an experiment by the radio host Christopher Lydon and the software developer Dave Winer, and innovation was also evident in the approach to content. Namely, the stories from the field during the pre-election campaign for the American presidential elections were presented in a new way in these podcasts. Lydon explained it in this way: "It was a space where people could speak raw language, express angry attitudes, which the majority of the population wants to hear and believe in. Being authentic, being political, speaking the way we speak at home... that was a huge gift of the internet" (Locke, 2017, in Martinoli, 2020: 23). Adam Curry is often mentioned in the literature as the author of the first podcast. He very quickly gained great popularity with his podcast Daily Source Code which was based on his presenting style and sharing views on current events alongside popular music (Chen, 2009, in Martinoli, 2020). Very soon after that, in 2006, the first academic texts on podcasting appeared, highlighting the advantages of podcasting over traditional radio broadcasting. As Martinoli suggests, there is no consensus in academia on the meaning of the term podcast or a single definition of podcast (Martinoli, 2020). She cites the definition given by the authors Morris and Terra: "A podcast is not an invention at all, but a convergence of existing technologies, processes, ideas. Podcasting can be a perfect example of this principle - and the change it brings to people's attitudes towards radio, music collections, books, education" (Morris and Terra, 2006: 11, in Martinoli, 2020: 25).

As the previously mentioned authors stated, podcasts marked a new attitude of the audiences towards radio without abandoning the affirmation of radio through its basic means of expression such as speech and voice and through a close connection with the audience. In relation to radio podcasts, it brings changes in several aspects: regarding content style and presentation, building closer relationships and community with listeners, engaging listeners in the production process and introducing new billing models for content produced in the form of podcasts (Martinoli, 2020).

There are two periods of podcasting development: the first one was between 2004 and 2014 when already broadcast radio shows were published as podcasts, and the second period which begins in 2014 when the content intended only for online platforms was produced, and the podcast developed as an independent and original media form (Lindeberg, 2019, in 
Martinoli, 2020). For example, the $B B C$ has been posting radio content online in the form of podcasts since 2004, but these were of secondary importance for a long time. In 2015, the $B B C$ invested more in publishing content that was available only online (Lindeberg, 2019). Although the print media was initially handicapped by the lack of audio content that could be used from the mainstream media and published online in the podcast form, the British Guardian launched a podcast of the original content that was "more like the radio than a podcast" (Lindeberg, 2019: 12). In the second phase, the audience had higher expectations from this media content and producers in Britain went beyond the strict tradition of the $B B C$ (Lindeberg, 2019). Given that there are both practices from the two phases of podcast development today, Newman and Gallo distinguish two types of podcasts: the first one is the native podcast - original audio content prepared for audio broadcast on demand which was not previously broadcast on radio or television, and another, catch up radio which implies content that is available for listening online and has previously been broadcast on radio or television (Newman \& Gallo, 2019).

Commercial radio stations have almost completely suppressed content which is becoming the most important component of podcasts. This is also shown by the research conducted by the Reuters Institute for Journalism, which takes content as the main criterion for classifying podcasts. Research conducted by this Institute in four countries shows that the most popular podcasts are those talking about society and culture (Lindberg, 2019). By country, it looks like this: in Sweden, Germany and Australia, podcasts dedicated to society and culture are the most popular ones; in Great Britain, the most popular podcasts are dedicated to comedy while podcasts dealing with topics related to society and culture are second. The content is classified into the following categories: Comedy, Society and Culture, News and Politics, Arts, Sports, Health, Business, Education, Kids and Family, Religion, Music, Games and Hobbies, Personal Journals, Fashion and Beauty, Science and Medicine, Technology and TV \& Film. Another criterion that is taken into account during the classification of podcasts is the type of content producer that indicates another important characteristic and that is that podcasts are a field in which many people can try themselves - that is, it can be amateurs who want to talk about a certain topic. The categories of podcast producers, according to this research, are: "Independent publisher (no companies, individual people publishing their podcasts on platforms), public radio (e.g., Sveriges Radio, BBC), podcast companies (e.g., Wondery, Acast), newspapers / magazines (Die Zeit, the Australian), other media companies (Bonnier), commercial radio (SBS, Ilikeradio) or governmental bodies or NGOs (NHS)" (Lindberg, 2019: 41). The most common producers of podcasts are independent publishers: in Germany (55\%), Great Britain (49.5\%), Australia (33\%) and Sweden (27.3\%) (Lindberg, 2019).

By highlighting the need to focus podcast analysis on theoretical postulates related to the digital media environment, Martinoli points out that there are new audience experiences, new insights and new use of media content (Martinoli, 2020). She lists several podcast characteristics which she defines as social media by accepting the UNESCO definition of social media which "simply defines social media in relation to their ability to nurture human relationships through technology, enabling better, faster and more continuous social interaction between users" (UNESCO: 2011, in Uzuegbunam \& Uzochukwu, 2016: 4, in Martinoli, 2020: 30). This means that the features of social media such as openness, web- 
generated, user-friendly and convenience for social networking also belong to the podcast. The characteristics of the podcast mentioned by Martinoli are: it is part of the exchange of information (conversational media), easy spreading of content (spreadable media), interactivity, availability on different platforms, personal production and reception of content (personal media), the audience actively searches and selects content (pull media), immersion and convergence (Martinoli, 2020). We will not discuss all these characteristics mentioned by Martinoli here. We will discuss some that we consider more prominent than others because podcasts use them fully such as interactivity, convergence, and immersion. There is a strong agreement among theorists that interactivity is one of the key characteristics of digital media. Jens Jensen defines interactivity as "a measure of a media's potential ability to let the user exert an influence on the content and/or form of the mediated communication" (Jensen, 1998: 201). Sally McMillan starts from the interpretation of interactivity that is the most common in literature, and that is that interactivity has three planes depending on the relationship in question: human-to-human interactivity, humanto-computer interactivity and human-to-content interactivity (McMillan, 2005). When we link interactivity with podcasting, we refer to creating the possibility for users to listen to podcasts where they want and when they want, to be able to download them irrespective of the program schedule of any radio company and the most important form of interactivity is the possibility for users to further share podcasts that they have downloaded or created themselves (Martinoli, 2020). The basis for convergence as a social change was provided by technological convergence, which enabled the same content to be easily translated into different media. Moreover, there was the convergence of media services and a change in the role of the audience, which now has an active role in such a changed media world (Foust, 2017; Jenkins, 2006; Milivojević, 2018). When we talk about convergence, in addition to the technical-technological aspect, we must also include the movement of the media market, "which takes place at the level of content, media forms, distribution methods, consumption of media content, etc." (Martinoli, 2020: 38). Podcasts are an example of media form created by the convergence at the level of technology, content and audience (Martinoli, 2020). The way the audience listens to podcasts - using headphones that set them apart from the rest of the world, the possibility of audio expression through music, speech and sounds, as well as storytelling techniques make the audience's immersive experience possible. Podcast listeners can be emotionally engaged and experience certain podcasts intensely. This could be defined as immersion. "Immersive media have the potential to strongly influence the emotions of users, their sense of presence and engagement" (Immersive Media Experiences, 2014, in Martinoli, 2020: 37). This feature is especially attributed to documentary types of podcasts (Martinoli, 2020).

\section{Podcasts in Serbia: Research results and discussion}

The first podcasts in Serbia appeared in 2005, almost at the same time as everywhere else in the world (a year later). It was the endeavor of the media house B92 comprising a radio, television and website, which wanted to get another channel for disseminating information content broadcast on radio (radio shows: Ritam srca and Kažiprst) and 
television (TV show Utisak nedelje) (Martinoli, 2020). The same as everywhere else in the world, in the first years of the development of podcasting in Serbia, mostly audio content was produced as podcasts, which had already been broadcast on one of the radio stations. During the second phase, podcasts were exclusively produced for online listening. At this stage, in Serbia as well, podcasts are launched by the media and other organizations, journalists and enthusiasts. Many of them do so in search of a field in which their freedom of speech will not be restricted. At the same time, podcast technology is still used by radio stations to give their listeners the opportunity to download and listen to missed shows on their websites (for example, Radio Belgrade - public radio service).

The number of podcasts is on the rise - in February 2019, there were 88 podcasts in Serbia (Martinoli, 2020) and today there are 203 podcasts on the site aggregator https://podcast.rs/ from Serbia and the region. The thematic diversity is great and there are the following areas: society (96 podcasts), entrepreneurship (38), sports (28), technology (28), news (21), pop culture (20), art (12), health (12), science (9) and education (9).

Some podcasts that publish news and information content have been launched by media companies: news agencies - Beta and Fonet, online media - Krik, Istinomer and Nova.rs, and newspaper - daily Danas (Table 1). These podcasts make up $10.3 \%$ of the total number of podcasts. The popularity of one type of podcasts - daily news podcasts - is significant and has a growing trend in the world. "Daily news podcasts make up less than $1 \%$ of all those produced but account for more than $10 \%$ of the overall downloads in the US and 9\% in France and Australia, according to the analysis of publicly available data. These shows are clearly punching well above their weight with audiences and have played an important role in helping to inform the public about a range of subjects, including coronavirus" (Newman and Gallo, 2020: 5). The number of daily news podcasts is growing and Newman and Gallo have recorded the existence of 102 daily news podcasts in six countries in the West - the United States, the United Kingdom, Australia, France, Sweden and Denmark (Newman and Gallo, 2020).

Table 1 News podcasts in Serbia examples compared

\begin{tabular}{|c|c|c|c|c|c|c|c|}
\hline $\begin{array}{l}\text { Podcast } \\
\text { name }\end{array}$ & $\begin{array}{l}\text { Danas } \\
\text { Podcast }\end{array}$ & $\begin{array}{c}\text { Beta } \\
\text { Podcast }\end{array}$ & Focast & U mikrofon & KRIK naglas & Retrovizor & $\begin{array}{l}\text { Podkast } \\
\text { Nova.rs }\end{array}$ \\
\hline $\begin{array}{l}\text { Medium that } \\
\text { founded the } \\
\text { podcast }\end{array}$ & Danas, daily & $\begin{array}{l}\text { News } \\
\text { agency } \\
\text { Beta }\end{array}$ & $\begin{array}{l}\text { News } \\
\text { agency } \\
\text { Fonet }\end{array}$ & $\begin{array}{l}\text { Istinomer, } \\
\text { online } \\
\text { medium }\end{array}$ & $\begin{array}{l}\text { KRIK, online } \\
\text { medium }\end{array}$ & $\begin{array}{l}\text { Istinomer, } \\
\text { online medium }\end{array}$ & $\begin{array}{l}\text { Nova. } \\
r s, \text { online } \\
\text { medium }\end{array}$ \\
\hline Launch & April 2020 & May 2020 & May 2020 & March 2019 & January 2020 & $\begin{array}{l}\text { November } \\
2018\end{array}$ & $\begin{array}{l}\text { October } \\
2020\end{array}$ \\
\hline Host & Journalists & Beta & Fonet & $\begin{array}{l}\text { Journalist, } \\
\text { Danica Vučenić }\end{array}$ & Krik & Istinomer & Nova.rs \\
\hline Format & $\begin{array}{l}\text { Commentary } \\
\text { of main } \\
\text { headlines of } \\
\text { the week }\end{array}$ & News & One story & Interview & $\begin{array}{l}\text { "Behind the } \\
\text { story" }\end{array}$ & Commentary & Interview \\
\hline Length & 30-35 mins & 5 mins & 5-30 mins & $35-40$ mins & $15-25$ mins & 5 mins & $25-60 \mathrm{mins}$ \\
\hline
\end{tabular}

Although podcast as a new media form in Serbia appeared very quickly after it appeared everywhere else in the world and regardless of the fact that the number and 
type of content is growing, there is still no monetization of this content (Martinoli, 2020). Only one crowdfunding-based podcast is sustainable ${ }^{6}$ and some are trying to generate revenue from advertisers (Agelast and Podcast Nova RS, for example). Some podcast authors in Serbia believe that podcasts should stay outside of the media business. This refers to those podcasts that affirm the alternative and underground social and art scene. "Podcasts should be underground, alternative, other sounds..." (Nebojša Krivokuća, podcast Prešlicavanje, in Martinoli, 2020: 187). The main reasons why podcasts do not make money yet are that the audience does not know enough about this media form, the offer is still not wide, there are financial barriers on the part of users, technological barriers that make access to content difficult and low response of advertisers (Martinoli, 2020). This is how Newman and Gallo present the situation on the global media scene: "Some commercial publishers are already deriving significant revenue from podcasts, especially in the United States. More than half of Slate's total revenue now comes from podcasts. NPR is expecting to earn $\$ 55 \mathrm{M}$ from podcasting next year, overtaking radio in terms of sponsorship income. But outside the English-speaking world and in smaller markets, monetization is far more challenging, with lower consumption and much lower interest from advertisers. But short-term revenue is often not the only motivation. Publishers see podcasts as a good way to build brand awareness and loyalty, which some hope may eventually transfer into subscriptions or donations" (Newman and Gallo, 2020: 6).

Podcast audience research as part of the overall media scene in Serbia was for the first time conducted by the Center for Media Research of the Faculty of Political Sciences in Belgrade (2020) Informing in the digital environment in Serbia. "The research was conducted on a dedicated sample -people who use the Internet at least once a week to learn about current events were surveyed. The findings presented in this research refer to the Internet population older than 16 years of age (without the upper age limit) on the territory of the entire Republic of Serbia, taking into account gender, age, education, region and type of settlement" (Center for Media Research, 2020: 13). The results highlight this area of media scene:

- $\quad 35 \%$ of participants listened to podcasts in the previous month.

- The largest share is made by those users who listened to the news podcasts, politics and international events $(17 \%)$. Those who listened to podcasts related to science, technology, art and health (15\%) (Center for Media Research, 2020) came second.

- "Those who listen to podcasts point out their advantages: more than one half think that podcasts allow them to better understand various topics than it is the case with other media services (57\%); they offer a more interesting approach to news $(56 \%)$ and give a wider range of topics and perspectives $(52.5 \%)$. Slightly less than one half of the participants think that podcasts are more suitable than other media services to provide information (49\%)"

\footnotetext{
${ }^{6}$ See more about this podcast (Alarm) in the article: Alternativni izvori finansiranja medijske produkcije: studija slučaja alternativnog onlajn audio formata "Alarm" [Alternative Sources of Media Production Funding: Case Study of Alternative Online Audio Format "Alarm"] (Drašković\& Prodanović, 2017).
} 
(Center for Media Research, 2020: 23).

- Looking at age groups, young people listen to podcasts the most (45\%), but also approximately a third of online users are older (Table 2).

Table 2 Podcast listeners in Serbia by age group

\begin{tabular}{|c|c|}
\hline \multicolumn{2}{|c|}{ Podcast listeners by age group } \\
\hline $16-24$ & $45 \%$ \\
\hline $25-34$ & $41 \%$ \\
\hline $35-44$ & $31 \%$ \\
\hline $45-54$ & $31 \%$ \\
\hline $55+$ & $25 \%$ \\
\hline
\end{tabular}

Source: Center for Media Research (2020: 23)

\section{Conclusion}

The results show that podcasts as a new media form are a growing field in Serbia - their number is increasing, there is an audience that is interested in this type of content presentation and points out that podcasts allow a certain topic to be explained in more detail. Since podcast technology is cheaper than radio and television broadcasting and since its broadcasting does not require the permission of the regulatory body, it is run by other companies, not just media companies. Such an example is the podcast Protok which has been founded by a company working in the field of new technologies with the aim of analyzing topics related to the relationship between society and technology (Mihajlov Prokopović, Jevtović \& Jovanović, 2019).

When it comes to the relationship between journalism and podcasts in Serbia, the results show that there are podcasts that broadcast journalistic content. The initiators of these podcasts are the mainstream media and journalists who work outside the media organizations. Media organizations launch podcasts as part of their specific media offer that is in line with the type of journalism nurtured in the parent medium. For example, on the front page of the Danas podcast, there is only one sentence: "Journalists of the Danas daily comment on the most popular news from the previous week". Most of these podcasts were launched in 2020. If we compare the number of daily news podcasts in Serbia with the development trend in the developed world which is on the rise, there are still very few daily news podcasts. These are: FoCast, Beta podcast and Podcast Nova.rs.

It can be concluded that the podcast that we called the individual endeavor of the author, considering that it is realized outside the media institution, is a freer form of expression and is often very popular - for example, podcasts Daško and Mladja and Agelast. Both of these podcasts are produced by journalists who have launched their own podcasts. As an example, we quote a part of the text from the title page of the Agelast podcast: "Through conversations and travels, this is my search, my attempt to escape from nonsense. The Agelast podcast is a project by Galeb Nikačević". 
Also, when we talk about the diversity of content that is placed through podcasts, it can be noticed that some traditional journalistic genres, while adapting to the new media form, can also be found in podcasts. Such is the case, for example, with film critics who have found their place in podcasts through a specific discourse on art - for example, the podcast Remarker: Zadovoljstvo u tekstu (engl. Remarker: Pleasure in Text).

\section{References}

Allan, S. (2006). Online News: Journalism and the internet. Glazgov: Bell and Bain Ltd. Boczkowski, P. (2004). Digitizing the news: innovation in online newspapers. Massachusetts: The MIT Press.

Boczkowski, P., Mitchelstein, E. (2017). "Incidental News: How Young People Consume News on Social Media". Proceedings of the 50th Hawaii International Conference on System Sciences, pp. 1785-1792.

Centar za medijska istraživanja [Center for Media Research] (2020). Informisanje $u$ digitalnom okruženju $u$ Srbiji [Informing in the digital environment in Serbia]. Beograd: Fakultet političkih nauka, Univerzitet u Beogradu. Available on: http://centarzamedije.fpn.bg.ac.rs/wp-content/uploads/2020/10/informisanje-udigitalnom-okruzenju-2020.pdf (Accessed April 17, 2021).

Dašić, M. (21 October 2020). “Da li čuješ, mila, moga konja podkas' - podkasti u Srbiji, kako rade i da li to iko sluša?" ["Podcasts in Serbia, how they work and does anyone listen to that?'] Noizz. Available on: https://noizz.rs/big-stories/podkasti-u-srbijikako-rade-i-da-li-to-iko-slusa/s7vj4p4 (Accessed May 14, 2021).

Drašković, B., Prodanović, D. (2017). Alternativni izvori finansiranja medijske produkcije: studija slučaja alternativnog onlajn audio formata Alarm [Alternative Sources of Media Production Funding: Case Study of Alternative Online Audio Format Alarm]. Ed. D. Pralica \& N. Šinković. Digitalne medijske tehnologije i društveno-obrazovne promene 7 (pp. 61 -71). Novi Sad: Filozofski fakultet, Odsek za medijske studije.

Deuze, M. (2007). Media work. Cambridge: Polity Press.

Fidler, R. (2004). Mediamorphosis [Mediamorphosis]. Beograd: Clio.

Foust, J. C. (2017). Online journalism: principles and practices of news for the web. London and New York: Routledge.

Hermida, A. (2014). Twitter as an Ambient News Network. Ed. K. Weller, A. Bruns, J. Burgess, M. Mahrt \& C. Puschmann. Twitter and Society. (pp. 359-373). New York: Peter Lang Publishing.

Jenkins, H. (2001). Convergence? I diverge. Available on: https://www.technologyreview. com/2001/06/01/235791/convergence-i-diverge/ (Accessed May 14, 2021).

Jenkins, H. (2006). Convergence Culture: Where Old and New Media Collide. New York and London: New York University Press.

Jensen, J. F. (1998). "Interactivity: Tracking a new concept in Media and Communication Studies”. Nordicom Review. 1/1998, pp. 185-204. 
Kung, L. (2015). Innovators in digital news. London, New York: I. B. Tauris.

"Lista podkasta" [“List of podcasts"] (May 14, 2021). https://podcast.rs/lista-podkasta/

Lindeberg, A. (2019). So You have a podcast? What broadcasters and newspapers are doing with new forms of audio. Oxford: The Reuters Institute for the Study of Journalism. Available on: https://reutersinstitute.politics.ox.ac.uk/sites/default/files/2019-08/ Lindberg\%20-\%20so\%20you\%20have\%20a\%20podcast.pdf (Accessed April 17, 2021).

Martinoli, A. (2020). Prvih 15 godina podkastinga: od eksperimenta do održivog medijskog biznis modela [The first 15 years of podcasting: from experiment to a sustainable media business model]. Beograd: Fakultet dramskih umetnosti.

McMillan, S. J. (2005). "The researchers and the concept: moving beyond a blind examination of interactivity". Journal of Interactive Advertising, 5(2), pp. 1-4.

Mihajlov Prokopović, A., Jevtović, Z., Jovanović, Z. (2019). "Digitalni izazovi lokalnih medija Nišavskog okruga" ["Digital challenges of local media of the Nišava district"]. CM: Communication and Media, XIV(46), pp. 5-32.

Milivojević, S. (2017). "Šta je novo u novim medijima?" [“What's new in new media?”] Reč, 87/33, pp. 159-172.

Negropont, N.(1998). Biti digitalan [Being digital]. Beograd: Clio.

Newman, N. (2021). Journalism, Media, and Technology Trends and Predictions 2021. Oxford: Reuters Institute for the Study of Journalism. Available on: https://reutersinstitute.politics.ox.ac.uk/sites/default/files/2021-01/Newman Predictions_2021_FINAL.pdf(Accessed April 17, 2021).

Newman, N., Fletcher, R., Schulz, A., And1, S., Nielsen, R. K. (2020). Reuters Institute Digital News Report 2020. Oxford: The Reuters Institute for the Study of Journalism. Available on:https://reutersinstitute.politics.ox.ac.uk/sites/default/files/2020-06/ DNR_2020_FINAL.pdf (Accessed April 17, 2021).

Newman, N., Gallo, N. (2019). News Podcasts and the Opportunities for Publishers. Oxford: The Reuters Institute for the Study of Journalism. Available on: https:// reutersinstitute.politics.ox.ac.uk/sites/default/files/2019-12/Newman_Gallo_ podcasts_FINAL_WEB.pdf(Accessed April 17, 2021).

Paulussen, S. (2016). Innovation in the Newsroom. Ed. T. Witschge, C. W. Anderson, D. Domingo \& A. Hermida. The SAGE Handbook of Digital Journalism. (pp. 192-206). London: Sage.

"The Daily" (13 May 2021). https://www.nytimes.com/column/the-daily

Weiss, A. S., Joyce, V.M.H. (2009). "Compressed dimensions in digital media occupations: journalist in transformation”. Journalism, 10(5), pp. 587-603.

\section{PODKASTI I NOVINARSTVO}

Apstrakt. Primena novih tehnologija u novinarstvu doprinosi razvoju novih formi za novinarski sadržaj. Podkast koji predstavlja sadržaj postavljen onlajn i omogućava onlajn korisnicima da mu pristupe kad žele i koliko puta žele doživljava kontinuirani 
uspeh u svetu (Newman, 2021). Ovaj razvoj doveo je i do sadržajne raznovrsnosti podkasta, a pristup temama samo je kod nekih podkast serijala novinarski. Autori podkasta mogu biti novinari, kao i drugi ljudi, korisnici interneta, a ponekad i slavne ličnosti. Tako na primer, predviđa se da će se ove godine među platformama i velikim medijima voditi ,,bitka za zvezde”. Cilj ovog rada je da mapira upotrebu podkasta u Srbiji, pošavši, pre svega, od podkasta kao tehnologije novinarstva. Pre nekoliko godina tradicionalni mejnstrim mediji u Srbiji pokušavali su da održe korak u onlajn okruženju i da povećaju posetu na svojim onlajn izdanjima. Rezultati ovog istraživanja pokazuju da se podkast kada je novinarstvo u pitanju razvija na dva načina: kao deo onlajn medija i kao individualni poduhvat autora. Može se zaključiti da podkast koji smo nazvali individualni poduhvat autora s obzirom da se realizuje van medijske institucije predstavlja slobodniju formu izražavanja i često je veoma popularan. Najzad, s obzirom na to da je podkast tehnologija jeftinija od radijskog ili televizijskog emitovanja programa i da za njegovo emitovanje nije potrebna dozvola regulatornog tela pokreću ga i druge kompanije, a ne samo medijske kompanije.

Ključne reči: podkast, novinarstvo, digitalne tehnologije, onlajn publika, mediji 